\title{
Techno-economic analysis of a combined cooling, heating and power system based on hot sedimentary aquifer for hotel building in tropical countries
}

\author{
Heru Prasetio ${ }^{1}$, Kezia Dara Euodia ${ }^{1}$ and Widodo Wahyu Purwanto ${ }^{1, *}$ \\ ${ }^{1}$ Department of Chemical Engineering, Faculty of Engineering, Universitas Indonesia, Kampus UI Depok 16424 Indonesia
}

\begin{abstract}
Low enthalpy geothermal based Combined Cooling, Heating and Power (CCHP) system for building is expected can increase energy efficiency and reduce carbon dioxide emission. The aim of this study is to assess techno-economic performances of a CCHP for hotel building in tropical countries with total energy demand of $7.64 \mathrm{MW}$. The fresh geothermal fluid was divided by $15 \%$ to power generation system of Organic Rankine Cycle (ORC) and the waste heat merged with the rest fresh geothermal to absorption refrigeration system and heating systems. Cycle Tempo and COMSOL are used to simulate CCHP system and a borehole of hot sedimentary aquifer (HSA), respectively. The simulation results indicate that total CCHP system efficiency is $36.61 \%$ consist of ORC efficiency and absorption cycle efficiency are $12.77 \%$ and $57.88 \%$, respectively with emission reduction of 1.4 ton $\mathrm{CO}_{2}$ eq. per year compare to conventional grid electricity. The best business scheme was $\mathrm{BOO}$ with financial incentives, which were tax allowance, soft loan, and grant. Therefore, the production prices were $0.08 \mathrm{USD} / \mathrm{kW}$ th, 0.10 $\mathrm{USD} / \mathrm{kW} \mathrm{eh}$, and $12.03 \mathrm{USD} / \mathrm{MMBtu}$ for cooling, electricity, and heating respectively.
\end{abstract}

\section{Introduction}

Regarding to increase energy efficiency, Indonesia has target to reduce $1.7 \%$ it in every year commercial sector [1]. Despite energy demand in commercial sector for space cooling, lighting, space and water heating are growing significantly, but current energy efficiency implementations are not having a substantial effect in achieving the target. Therefore, the study must be taken care. The importance of energy efficiency in Indonesia was shown on the escalation of energy demand by $3.99 \%$ in $2000-2014$ [2]. Final energy consumption of Indonesian's commercial building was $5.64 \%$ or equal to 38 million BOE in 2016 [3]. Electricity and cooling are the main energy needs for commercial building in tropical countries like Indonesia. The number of hotel building in 2016 up to 2,387 hotels with 233,007 rooms [4].

Indonesia has geothermal potency in all area for both high-temperature and low-temperature. The potency of high-enthalpy geothermal is $16,134 \mathrm{MW}_{\mathrm{e}}$ and lowenthalpy geothermal near high-temperature resource is 7,886 $\mathrm{MW}_{\mathrm{e}}$ [5]. In fact, most locations in Indonesia can be considered as medium enthalpy because the temperature range on aquifer is about $100^{\circ} \mathrm{C}-200^{\circ} \mathrm{C}$ [6]. Geothermal resources in urban area can be retrieved from Hot Sedimentary Aquifer (HSA).

CCHP is combinations that produce electricity and heat from the same energy resource. Previous studies on energy technologies related to energy efficiency are cooling and heating from geothermal and photovoltaic for a building in Romania [7], CCHP from geothermal and natural gas for an office building in China [8], combine heat and power from lignite and geothermal for sustainable buildings in Turkey [9], and combine heat and power from natural gas for small commercial buildings in North America [10]. Many studies use natural gas as main energy resource $[\mathbf{8 , 1 0 - 1 2}]$ and combined energy resource or hybrid [7,9]. The study in tropical country was done in Thailand, which Raksaskulwong [13] reviewed direct usage of lowenthalpy geothermal as direct use and Chaiyat [14] worked on the prototype of CCHP from low-enthalpy geothermal.

The aim of current study is to assess technoeconomic performances of a CCHP using HSA as energy resource in tropical country. The geothermal energy is taken from HSA with one production well and one injection well. Moreover, the simulation is demanddriven so that the downstream is going to be simulated first and then checked if the medium-enthalpy geothermal resource is sufficient. Finally, the result is compared with conventional for economic aspects to find the most feasible business scheme.

\footnotetext{
Corresponding author: widodo@che.ui.ac.id
} 


\section{Materials and methods}

\subsection{Energy demand}

The assumptions of projected hotel are total hotel area is $45,000 \mathrm{~m}^{2}$ or equal to 45 floors, total hotel room of 600 in which 1 room consists of 2 guests, and occupancy rate of $61.5 \%$ [15]. Total energy consumption in tropical countries to achieve satisfactory is $320 \mathrm{kWh} / \mathrm{m}^{2}$ per year [16]. In tropical countries, cooling is very important so that cooling demand is $56 \%$ of total energy consumption [17] and the rest of it is electricity demand. Total water consumption per guest night is 812 L [18]. Heating demand for hot water is calculated with specific heat formula for temperature range of $25^{\circ} \mathrm{C}$ to $60^{\circ} \mathrm{C}$. Additionally, facilities' heating demand volume size is assumed. The temperature for hot tub, sauna, and hot spring pool is $60-70^{\circ} \mathrm{C}, 70-100^{\circ} \mathrm{C}$, and $35-70^{\circ} \mathrm{C}$, respectively. Table 1 summarizes energy demand for the proposed hotel.

Table 1. Energy Demand of Proposed Hotel

\begin{tabular}{|l|r|r|}
\hline Total hotel area & \multicolumn{2}{|c|}{$45000 \mathrm{~m}^{2}$} \\
\hline Total room & \multicolumn{2}{|c|}{600} \\
\hline Occupancy rate & \multicolumn{2}{|c|}{$61.5 \%$} \\
\hline Energy Demand & $\begin{array}{c}\text { Total Energy } \\
(\mathrm{kW})\end{array}$ & Share (\%) \\
\hline \multicolumn{2}{|c|}{920.55} & $12.05 \%$ \\
\hline Cooling demand & 723.29 & $9.47 \%$ \\
\hline Electricity demand & 509.78 & $6.67 \%$ \\
\hline Hot Water demand & 211.01 & $2.76 \%$ \\
\hline Sauna demand & 70.00 & $0.92 \%$ \\
\hline Hot Tub demand & 5206.25 & $68.14 \%$ \\
\hline Hot Spring & $\mathbf{7 6 4 0 . 8 8}$ & $\mathbf{1 0 0 . 0 0 \%}$ \\
\hline $\begin{array}{l}\text { Total energy } \\
\text { demand }\end{array}$ & &
\end{tabular}

\subsection{CCHP simulation}

The assumptions for CCHP are steady state conditions, constant isentropic efficiency for turbine and pump, outlet condenser is saturated liquid, and outlet generator and evaporator on absorption refrigeration system (ARS) is saturated ammonia gas. CCHP simulation uses Cycle Tempo program. Although geothermal heat source is not available on Cycle Tempo, heat sink suits to represent geothermal heat source which assumption conditions are $140^{\circ} \mathrm{C}$ and 10 bar [19]. The first cycle is organic Rankine Cycle (ORC) as power generation with R134a as working fluid. Geothermal boiler on ORC has pinch temperature of $7^{\circ} \mathrm{C}$. The operating conditions of ORC use pressure to enthalpy $(\mathrm{p}-\mathrm{h})$ diagram to determine the best conditions. The second cycle is ARS as cooling system with ammonia - water as working fluid. The generator boiler, condenser, super-heater, and evaporator on ARS have pinch temperature of $5^{\circ} \mathrm{C}$, while absorber has pinch temperature of $10^{\circ} \mathrm{C}$. The most optimum temperature of generator boiler on ARS is about $130^{\circ} \mathrm{C}$ [20], so the closest it is the more efficient it becomes.
Water is heated with geothermal heat in a heat exchanger from $25-60^{\circ} \mathrm{C}$. Fig. 1 shows the CCHP system used in this study.

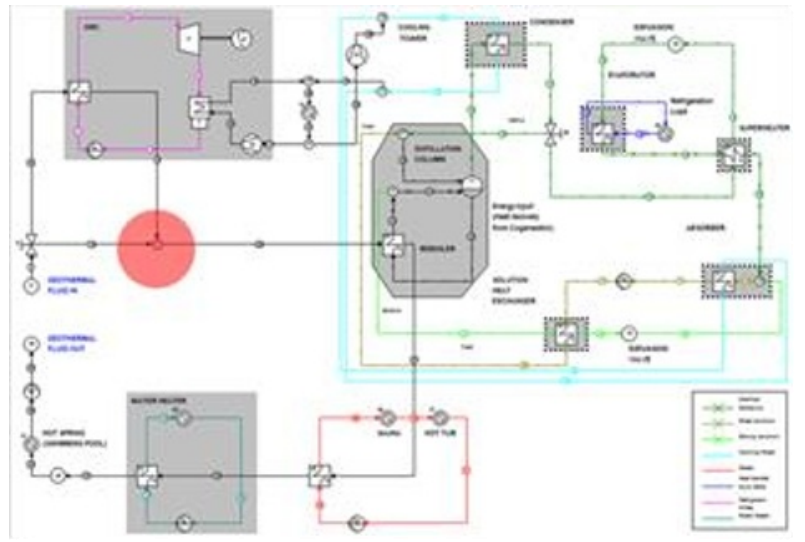

Fig. 1. CCHP system

Both hot tub and sauna facilities are in the same area so that fresh water circulates from facility that needs higher temperature to the lower one. As sauna needs higher temperature than hot tub, the circulation goes to sauna and hot tub with temperature range of $70-100^{\circ} \mathrm{C}$ and $60-70^{\circ} \mathrm{C}$.

\subsection{Borehole simulation}

The assumption for borehole simulation is steady-state. The borehole simulation uses COMSOL and only simulates production geothermal well as the best CCHP scenario. The heat source comes from Talang Akar aquifer (West Java) which has averagely $300 \mathrm{~m}$ thick and $145^{\circ} \mathrm{C}$ [21]. There are three layers, which top soil tends to have constant surface temperature in depth of 10 $-20 \mathrm{~m} \mathrm{[22]}$. The total depth to the aquifer is $2500 \mathrm{~m}$. The three layers have different soil thermal conductivity of 1,2 and $5 \mathrm{~W} / \mathrm{m} \mathrm{K} \mathrm{[23]} \mathrm{for} \mathrm{top} \mathrm{soil,} \mathrm{soil} \mathrm{and} \mathrm{aquifer}$ respectively. Since the mass flow rate is $36.7 \mathrm{~kg} \mathrm{~s}^{-1}$ so the diameter borehole diameter is 8-in nominal diameter and 12-in casing diameter [24].

The simulation uses two steps on COMSOL, which are heat transfer in porous media $(h t)$ and turbulence $k-\varepsilon$. Since the minimum required temperature is $140^{\circ} \mathrm{C}$ using turbulence flow for heat transfer in fluid. Input the boundary conditions as listed on Table 2 .

Table 2. Boundary Conditions on Borehole Simulation

\begin{tabular}{|l|l|}
\hline \multicolumn{2}{|l|}{$\mathbf{z = - 2 5 0 0}$} \\
\hline Soil Temperature $(h t)$ & $145^{\circ} \mathrm{C}$ \\
\hline Fluid Temperature $(h t)$ & $145^{\circ} \mathrm{C}$ \\
\hline Inlet Fluid $(s p f)$ & $1,3110 \mathrm{~m} / \mathrm{s}$ \\
\hline $\mathbf{z}=\mathbf{0}$ & $30^{\circ} \mathrm{C}$ \\
\hline Soil Temperature $(h t)$ & Outflow (default COMSOL) \\
\hline Outlet Fluid $(h t)$ & $\begin{array}{l}\text { Open Boundary (default } \\
\text { COMSOL) }\end{array}$ \\
\hline Outlet Fluid $(s p f)$ & Volume Force (-g_const*spf.rho) \\
\hline Gravity $(s p f)$
\end{tabular}




\subsection{Economics calculation}

The referred prices are $0.08 \mathrm{USD} / \mathrm{kWth}$ for cooling, 0.11 $\mathrm{USD} / \mathrm{kWh}$ for electricity, and $12.81 \mathrm{USD} / \mathrm{MMBtu}$ for heating gas. Capital expenditure (CAPEX) is 936 $\mathrm{USD} / \mathrm{kW}_{\mathrm{t}}$ for geothermal drilling, $3825 \mathrm{USD} / \mathrm{kW}_{\mathrm{e}}$ for ORC[25], $189 \mathrm{USD} / \mathrm{kW}_{\mathrm{t}}$ h for ARS [26], $12.6 \mathrm{USD} / \mathrm{kW}_{\mathrm{t}} \mathrm{h}$ for water heater [26], $8.38 \mathrm{USD} / \mathrm{kW}_{\mathrm{t}}$ h for sauna [26], and $9.74 \mathrm{USD} / \mathrm{kW}_{\mathrm{t}} \mathrm{h}$ for hot tub [26] (1 USD = 13,500 IDR). Operational expenditure (OPEX) is $2 \%$ of CAPEX for geothermal drilling [27] and 6\% of CAPEX for other systems [28]. The economics parameter must attain payback period of 10 years and IRR $>$ WACC. There are three business schemes option that is going to be studied, which are engineering, procurement and construction (EPC), build, operate and transfer (BOT), and build, own, and operate $(\mathrm{BOO})$ with financial incentives $(\mathrm{BOO}$ + FI). Table 3 shows the assumptions for three business schemes.

Table 3. Business Scheme Assumptions

\begin{tabular}{|l|l|l|l|}
\hline & EPC & BOT & BOO + FI \\
\hline Price Increment & $3 \%$ & $3 \%$ & $3 \%$ \\
\hline Salvage Value & $6.25 \%$ & 0 & $6.25 \%$ \\
& CAPEX & 0 & CAPEX \\
\hline Equity/Loan & $30 / 70$ & $30 / 70$ & $30 / 70$ \\
\hline Equity Rate & $14.48 \%$ & $14.48 \%$ & $14.48 \%$ \\
\hline Bank Loan Rate & $6.00 \%$ & $6.00 \%$ & $2.00 \%$ \\
\hline Loan Duration (years) & 15 & 10 & 20 \\
\hline Tax Rate & $25 \%$ & $25 \%$ & $10 \%$ \\
\hline Lifetime (years) & 30 & 20 & 30 \\
\hline
\end{tabular}

\section{Results and discussion}

\subsection{Energy demand}

Energy demand of five-star hotel building is estimated using engineering model based on quantity of services and energy intensity of services, comprises of thermal energy and electricity. The total energy demand estimation is $7,640.88 \mathrm{~kW}$ with its distribution is shown in Fig. 2.

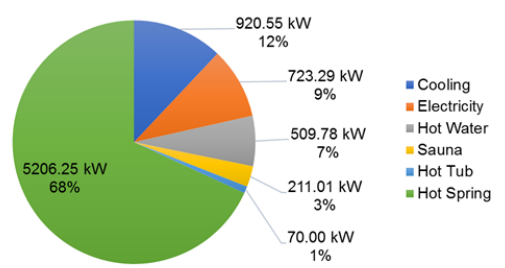

Fig. 2. Energy Demand Distribution

\subsection{CCHP system}

For the simulation, CCHP system splits $15 \%$ of fresh geothermal for ORC, then the waste heat merges with the rest fresh geothermal to enter the ARS and heating systems. The optimum conditions of ORC with R134a as working fluid before entering turbine are $120^{\circ} \mathrm{C}$ and 38 bar, while outlet turbine conditions are $50.5^{\circ} \mathrm{C}$ and 8.5 bar. The optimum conditions of ARS with ammonia water as working fluid are affected by incoming geothermal temperature so the outlet temperature of generator in ARS $123.8^{\circ} \mathrm{C}$. Because of that, the mass flow is only $36.7 \mathrm{~kg} \mathrm{~s}^{-1}$. Mass flow leads to pump power as it needs $185.28 \mathrm{~kW}$ to circulate the whole system.

The net energy produced by CCHP is revealed in Fig. 3. The energy efficiency of ORC, ARS, and total CCHP system is $12.77 \%, 57.88 \%$ and $36.61 \%$, respectively. It implies the ability of the systems to deliver the energy services. The efficiency of ORC with R134a as working fluid is $10 \%$ [25] and only depends on operating conditions. The most optimum generator outlet temperature is $130^{\circ} \mathrm{C}[\mathbf{2 0}]$, therefore the closest temperature to the optimum makes the ARS has higher efficiency. Since the system cannot reach the optimum temperature, the efficiency is only $57.88 \%$. This is due to the fresh geothermal is merged with waste heat from power generation system that results lower outlet temperature of generator.

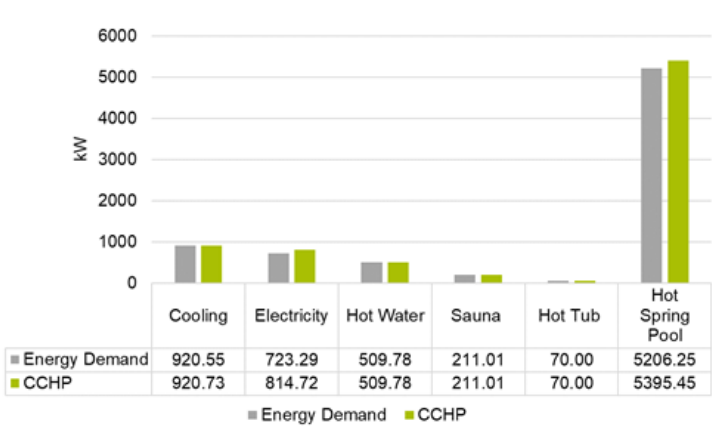

Fig. 3. CCHP Net Energy Production

CCHP with low-enthalpy geothermal reduces $\mathrm{CO}_{2}$ emission by 10 times compare to grid electricity. The CCHP produces the emission of $0.16-0.18$ ton $\mathrm{CO}_{2 \mathrm{eq}}$ per MWh [29]. Grid electricity of Perusahaan Listrik Negara (PLN) gives an emission intensity of 0.808 ton $\mathrm{CO}_{2 \text { eq }}$ per $\mathrm{MWh}$ because the main energy resource is coal [30]. For gas-based power plant is 0.4 tonCO $\mathrm{C}_{2 \text { eq }}$ per MWh [31]. Both PLN electricity and gas-based power higher emission rate than HSA-based CCHP system, thus the difference up to 1.4042 ton $\mathrm{CO}_{2 \text { eq }}$ per year.

\subsection{Borehole supply}

The simulation indicates that the output condition of geothermal fluid is $143.2^{\circ} \mathrm{C}$ as shown on Fig. 4. This can fulfil the needs on CCHP system. The model assumes that the pipe is located in low conductivity rock so that heat loss to the environment is negligible. Horizontal profile for velocity and temperature indicate turbulent flow along the borehole. Although the total temperature decline is small, temperature profile along borehole depth is segmented because of different soil layer characteristics. 


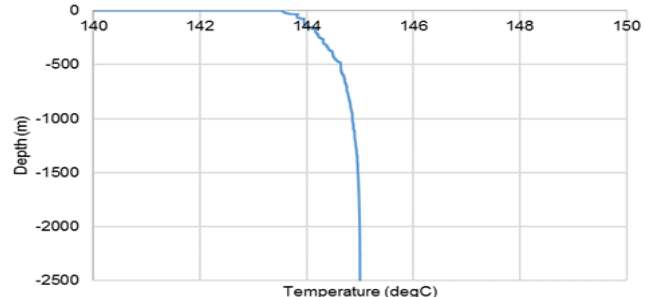

Fig. 4. Temperature profile of geothermal fluid

\subsection{Economics}

The capital expenditure (CAPEX) of the whole system is 18.64 million USD, the cost breakdown is shown on Fig. 5.

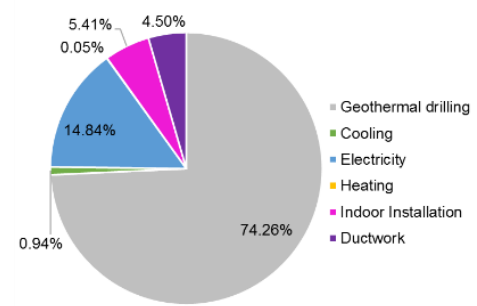

Fig. 5. Cost Breakdown

The geothermal drilling is share equipment for polygeneration. Hence, the cost of geothermal drilling is based on joint cost of heating, electricity, and cooling. The share of heating, electricity, and cooling is $72.37 \%$, $22.46 \%$, and $5.17 \%$, respectively.

The target of production costs is to reach willingness to pay. It means that production costs must be lower than conventional, which is levelized cost of electricity (LCOE) of air handling unit (AHU) $\left(0.08 \mathrm{USD} / \mathrm{kW}_{\mathrm{t}} \mathrm{h}\right)$, PLN electricity tariff $\left(0.11 \mathrm{USD} / \mathrm{kW}_{\mathrm{e}} \mathrm{h}\right)$, and pipeline gas tariff (12.81 USD/MMBtu).

From the production costs comparation, BOO with FI scheme is the best option for the project as represented on Fig. 6.

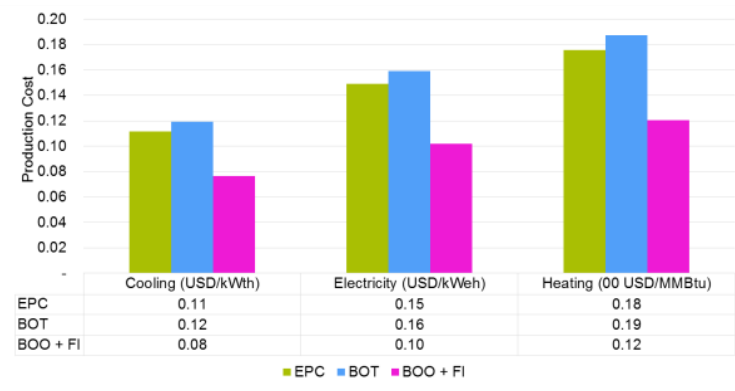

Figure 6. Production Costs Comparation

The $\mathrm{BOO}+$ FI can reach willingness to pay with final production costs of $0.08 \mathrm{USD} / \mathrm{kW}_{\mathrm{t}} \mathrm{h}, 0.10 \mathrm{USD} / \mathrm{kW}_{\mathrm{e}} \mathrm{h}$, and 12.03 USD/MMBtu for cooling, electricity, and heating respectively. A fiscal incentive through tax allowance from government is regulated by Ministry of Finance regulation number 3 year 2012 (No.3/PMK/2012). Tax allowance reduces income tax to $5 \%$ of $70 \%$ of net income for the first 6 years and $10 \%$ of net income for the rest lifetime. Although the government gives loan facility with lower bank loan rate for geothermal project, soft loan offers lower bank loan rate. The rate depends on London Interbank Offered Rate (LIBOR), which is $2 \%$ per year. Soft loan can be obtained from international bank such as Asian Development Bank or World Bank. Moreover, international organization grant on energy efficiency is feasible to get like Global Environment Facilities (GEF) that also focus on energy efficiency and help private sector to reach the same goals. In this experiment case, the grant is 3 billion USD, while it can be bigger depending on the organization's review.

CCHP with low-enthalpy geothermal resource is a good investment for both SPV and hotel management. SPV obviously gets profit with IRR of $13 \%$, payback period of 10 years, and NPV of 142,013 USD. Also, the credibility of SPV to have another project on energy efficiency is possible. Nonetheless, hotel management gets premium quality facilities and possible green building certification.

\section{Conclusion}

Total energy demand of hotel building is $7,649.88 \mathrm{~kW}$ in which mostly used for facilities. Besides, the energy supply arrangement divides $15 \%$ of fresh geothermal for $\mathrm{ORC}$ and then the waste heat merges with the rest fresh geothermal following systems. The total energy supply is $7,921.69 \mathrm{~kW}$ and total efficiency of $36.61 \%$. Additionally, the borehole system of 2,500 $\mathrm{m}$ depth and 8 -in diameter production well lifts surface geothermal fluid of $143.2^{\circ} \mathrm{C}$. To have production costs reach willingness to pay, build, own, operate (BOO) with fiscal incentives, soft loan, and international grant is applied. At last, the final production costs are 0.08 $\mathrm{USD} / \mathrm{kW}_{\mathrm{t}} \mathrm{h}, 0.10 \mathrm{USD} / \mathrm{kW}_{\mathrm{e}} \mathrm{h}$, and $12.03 \mathrm{USD} / \mathrm{MMBtu}$ for cooling, electricity, and heating, respectively.

This research is supported by the United States Agency for International Development (USAID) through the Sustainable Higher Education Research Alliance (SHERA) Program for Universitas Indonesia's Scientific Modeling, Application, Research and Training for City-centered Innovation and Technology (SMART CITY) Project, Grant \#AID-497-A1600004, Sub Grant \#IIE-00000078-UI-1.

\section{References}

[1] ASEAN Centre for Energy. The 5th ASEAN energy outlook 2015 - 2040. Jakarta, Indonesia: ASEAN Centre for Energy; 2017:36 - 83.

[2] Sugiyono A, Anindhita, Wahid L.M.A, Adiarso (Eds.). Indonesia energy outlook 2016. Jakarta, Indonesia: Agency for the Assessment and Application of Technology; 2016.

[3] Ministry of Energy and Mineral Resources. Handbook of energy \& economic Statistics of Indonesia. Final ed. Jakarta, Indonesia: Ministry of Energy and Mineral Resources; 2016.

[4] Number of accommodations, rooms, and beds 
available in classified hotel by province, 2000 2016. Statistics Indonesia Web Site. https://www.bps.go.id/linkTableDinamis/view/id/ 1096 Accessed October 24, 2017.

[5] Fauzi A. Geothermal resources and reserve in Indonesia: an update revision. Geo. Energ. Sci. 2015; $3: 1-6$.

[6] Gehlin S.E.A, Spliter J, Hellstrom G. Deep Boreholes for Ground Source Heat Pump Systems - Scandinavian Experience and Prospects. Paper presented at: ASHARE Winter Meeting; January 23 - 27, 2016; Orlando, Florida.

[7] Moldovan M.D, Visa I, Neagoe M, Burduhos B.G. Solar heating \& cooling energy mixes to transform low energy buildings in nearly zero energy buildings. Energy Procedia. 2014; 48: 924 $-937$.

[8] Liu W, Chen G, Yan B, Zhou Z, Du H, Zou J. Hourly operation strategy of a CCHP system with GSHP and thermal energy stirage (TES) under variable loads: A case study. Energy and Buildings. 2015; 93: 143 - 153 .

[9] Kilkis B. A lignite-geothermal hybrid power and hydrogen production plant for green cities and sustainable buildings. Int. J. Energy Res. 2011; 35: $138-145$.

[10] Ghaebi H, Midpour M, Karimkashi S, Rezayan O. Energy, exergy and thermoeconomic analysis of a combined cooling, heating and power (CCHP) system with gas turbine prime mover. Int. J. Energy Res. 2011; 35: 697 - 709.

[11] Mago P.J, Chamra L.M, Hueffed A. A review on energy, economical, and environmental benefits of the use of CHP systems for small commercial buildings for the North American climate. Int. j. Energy Res. 2009; 33: 1252 - 1265.

[12] Mohammadi A, Kasacian A, Pourfayaz F, Ahmadi M.H. Thermodynamic analysis of a combined gas turbine, ORC cycle and absorption refrigeration for a CCHP system. Applied Thermal Engineering. 2017; 111: 297 - 406.

[13] Raksaskulwong M. Update on Geothermal utilizations in Thailand. Paper presented at: World Geothermal Congress; April $19-25$, 2015; Melbourne, Australia.

[14] Chaiyat N, Kiatsiriroat T. Analysis of combined cooling heating and power generation from organic Rankine cycle and absorption system. Energy. 2015; $365-320$.

[15] Poh S, Rajan Y, Yean C.H. Indonesian Hotel Watch 2016. Singapore. HVS, 2016.

[16] Green Hotlier. Environmental management for hotels. International Tourism Partnership, 2014.

[17] Katili A.R, Boukhanouf R, Wilson R. Space
Cooling in Buildings in Hot and Humid Climates - A Review of the Effect of Humidity on The Applicability of Existing Cooling Techniques. Poster presented at: the 14th International Conference on Sustainability Energy Technology; August 25 - 27, 2015; Nottingham, UK.

[18] EarthCheck Research Institute. 2nd White Paper and Tourism and Water: From Challenges to Solutions. Australia: EarthCheck, 2014.

[19] Franco A, Villani M. Optimal design of binary cycle power plants for water-dominated, mediumtemperature geothermal fields. Geothermics. 2009; 38(4): 379 - 391.

[20] Colonna P, Gabrielli S. Industrial trigeneration using ammonia-water absorption refrigeration systems (AAR). Applied Thermal Engineering. 2003; 23: $381-396$.

[21] Putra S.D.H, Putri N., Suryantini N. Resource assessment. Indonesia. Geocap, ITB, 2016.

[22] Sanner B. Shallow Geothermal Energy. GHC Bulletin. June 2001: 19 - 25.

[23] Le Lous M, Dupuy A, Larroque F, Moignard A. Thermal performance of a deviated deep borehole heat exchanger: insights from a synthetic coupled model. Poster presented at: COMSOL Conference; 2015; Grenoble.

[24] Culver G. Drilling and well construction. In: Lienau P.J, Lunis B.C, eds. Geothermal Direct Use Engineering and Design Guidebook. 2nd ed. Oregon, US: Geo-heat Center; 1991: 115 - 151.

[25] Walraven D, Laenen B, D'haeseleer W. Influence of The Heat-Source Cost on Geothermal ORCS. Paper presented at: 3rd International Seminar on ORC Power Systems; October 12 - 14, 2015; Brussels, Belgium.

[26] Ebrahimi M, Keshavarz A. Combined Cooling, Heating and Power: Decision-Making, Design and Optimization. Oxford: Elsevier; 2015: 208.

[27] Sigfússon B, Uihlein A. 2015 JRC Geothermal Energy Status Report. Netherlands: European Commission; 2015.

[28] Chen J.M.P, Ni M. Economic analysis of a solid oxide fuel cell cogeneration/trigeneration system for hotels in Hong Kong. Energy and Buildings. 2014; 75: $160-169$.

[29] Mattson E, Mallozzi L, Mines G. Binary Power Plant CO2 Life Cycle Emmisions Including Isobutane Fugitive Leakage. Paper presented at: 42nd Workshop on Geothermal Reservoir Engineering; February 13 - 15, 2017; Stanford, California.

[30] Ministry of Energy and Mineral Resources. Rencana Usaha Penyediaan Tenaga Listrik. Jakarta: Ministry of Energy and Mineral 
Resources; March 29, 2017: VI-85.

[31] International Energy Agency (IEA). CO2

Emissions from Fuel Combustion: Beyond 2020

Documentation.

http://www.iea.org/statistics/topics/CO2emissions

I. Published 2014. Accessed 30 November 2017. 